Original scientific paper - Izvorni znanstveni rad

UDK: 637.1

\title{
Value-based food chains as an opportunity to improve the economic situation of dairy farms: a translog profit function approach
}

\author{
Jernej Prišenk ${ }^{1 *}$, Ivo Grgić2 , Magdalena Zrakić2, Jernej Turk ${ }^{1}$ \\ ${ }^{1}$ University of Maribor, Faculty of Agriculture and Life Sciences, Pivola 10, 2311 Hoče, Slovenia \\ ${ }^{2}$ University of Zagreb, Faculty of Agriculture, Svetošimunska 25, 10000 Zagreb, Croatia \\ Received - Prispjelo: 09.11.2017. \\ Accepted - Prihvaćeno: 18.04.2018.
}

\begin{abstract}
This paper utilizes available data sets and a single translog profit function to examine the performance of dairy farms operating in mountain and lowland areas, respectively. A translog profit model estimates reveal an apparent trend going toward explaining the better economic performance of highland dairy farms stemming from their capability to adjust accurately to underlying changes in the milk market. The empirical analysis finds mostly inelastic price elasticity trends. Translog profit model alleviates the path of understanding in explaining the better economic situation of these high-land dairy farms stemming from their capability to adjust adequately and promptly to ongoing changes in the milk market. Finally, the results of the study could at the same time deliver a new dimension in further debate about CAP post-2020 developments.
\end{abstract}

Key words: agro-food chain, value added, dairy farms, mountain regions, translog profit function

\section{Introduction}

On $31^{\text {st }}$ March 2015 the EU milk production quotas came to an end. Market projections indicate that the prospects for further growth remain strong - in particular for added-value products, such as cheese, but also for ingredients used in nutritional, sports and dietary products (European Commission, 2015). After one year of the milk quota being abolished, the weighted averages of cow's raw milk price on the EU level in May 2016 decreased from $30.73 € / 100 \mathrm{~kg}$ to $26.57 € / 100 \mathrm{~kg}$. A constantly decreasing trend in prices of cows' raw milk since December 2015 has been observed (European Commission, 2016).

Milk sector in Slovenia is very important from the economic aspect, since it represents $14 \%$ of the total value of agricultural production (MAFF, 2016). The similar decreasing trend, as in EU, can also be traced in Slovenia (e.g., in May 2016 down to $23.57 € / 100 \mathrm{~kg}$ ). The most worrying data is the raw milk price drop in April 2016 compared to April 2015 where the price changed for $-13 \%$ on the EU-28 level and for $-17 \%$ in Slovenia. Slovenia is one of six countries suffering a decrease in the price of raw milk during the period between April 2015 and April 2016. Prices became instable because of the imbalance between supply and demand of raw milk and surpluses of milk on the market. Average prices of milk products in the EU fell by $19 \%$ last year, nudged down by increasing production, less stockpiling of dried milk in China and a Russian import ban. The majority of negative economic consequences of instable EU milk market mostly concerns the farmers - especially from less favored areas such as mountain regions (with lower production capacity and small size of herds) (EuroActiv, 2016). 
Livestock farming, especially milk production, is a key activity in most mountain regions worldwide, providing regular and secure income (Bernet et al., 2001) and employment for mountain communities (Malla, 2007; European Parliament, 2013). Since Slovenian mountain and hilly regions are spread out over more than $70 \%$ of the total area, the preservation of farming is crucial from economic and social aspects (MAFF, 2016). Additionally, the mountain regions also express added values for dairy products (freshness, quality, better taste), which can go along with the fact that published rules for "mountain product" label were set in place, which clarifies other elements of EU quality labels (European Commission, 2014). Dairy farms also help a great deal to shape those landscapes and give to rural areas their distinctive character.

For the mountain dairy farms the solution might be the involvement into the local food chains with added values from mountain areas (referred to also as 'value-based food chains') (Stevenson et al., 2011). Characteristics of value-based food chains (VBFC) have been already presented by many papers (Stevenson et al., 2011; Vacas et al., 2014; Stevenson et al., 2008). VBFCs are not necessarily short food supply chains (Kneafsey et al., 2013), but the point is to express the added values, such as supporting the small farmers to improve their economic situations (Pirog and Bergendahl, 2012). VBFCs evenly spread the output values to all partners (actors) in the chain, and consumers often recognize the food products as the high quality food products produced under environmentally friendly production systems, with a positive direct and indirect returns to the local economy (Stevenson et al., 2011; Pearson et al., 2011; Witzke et al., 2009; Viithariju et al., 2005).

Due to a lack of relevant research studies supported by quantitative models for assessing the economic impacts of value-based food chains on primary actors (farmers), we decided to develop the econometric model to evaluate the economic viability of VBFC related to dairy farmers (primary actors). The analysis has been focused on disclosing the economic returns yielded by the econometric modelling approach - a translog profit function. The translog specification is a second-degree flexible function in prices and fixed inputs, with variable elasticities of substitutions and is considered as a second order approximation of any functional form (Beyers and Hassan, 2000). The same authors have used this parametric approach in estimating the structure of South African milk production technology. In another study (Mawa et al., 2014), authors describe profit efficiency of dairy farmers in Kenya using a translog function approach. Many possible indicators exist there for assessing the economic performance of a farm. Basically, these indicators can be divided into two sub-groups: (i) the efficiency measures from the field of productive efficiency measurement and (ii) the classical profitability indicators commonly used in practice within the field of farm management (Jan et al., 2014). However, productive efficiency measures were shown to be inappropriate to assess the overall economic performance of an enterprise (Musshof et al., 2009). Therefore, we rather used a profitability indicator commonly referred to as a 'restricted profit', described in more details in the following section.

This paper is structured as follows. A brief analysis of study area and data sources is followed by a description of the methodology and model development. Afterwards, the application of the model to ten local mountain food products is scrutinized. The results of applying the Translog profit function (model), along with a discussion, are described in the next section. The paper concludes with the main findings pertaining to the economic benefits enjoyed by the farmers as an integral part of VBFC. Finally, some recommendations are given for future related studies.

\section{Material and methods}

According to the value-based characteristics described above, we identified the value-based food milk in Slovenian mountain region. It is the VBFC with the key actor "Planika" dairy (referred to as Planika VBFC). Geographical Latitude of Planika dairy is $46^{\circ} 14^{\prime} 42.00^{\prime \prime} \mathrm{N}$ and Longitude is $13^{\circ} 35^{\prime} 6.00^{\prime \prime E}$. Approximately 150 to 200 (vary from year to year) small local dairy farms (within the range of $30 \mathrm{~km}$ ) are included in milk producing. The average size of mountain farm is above the Slovenian average (6.8 ha). Furthermore, the size of herd is smaller (between 8 and 10) compared to average dairy farm in Slovenia (15.2) (AIS, 2013). 
The main difference between VBFC and other forms of agri-food chains is in the expression of the (added) value ("Value" and / or "Value Added") chain, described by some authors (Pirog and Bergendahl, 2012). They conclude that the added value can be expressed in three different ways:

- by agricultural or food products made from raw materials which demonstrate their origin and therefore can achieve higher price on the market,

- protected designations of food products that expresses the geographical location, high quality of raw materials and / or the food safety,

- as an appropriate business relationships and interactions between the different actors in the food chain.

Some authors (Stevenson 2013; Pirog and Bergendahl, 2012; Stevenson et al., 2011; Stevenson et al., 2008) have developed a definition which describes the value-based food chains. The definition is mainly based on the description of the differences between the value-based food chains and conventional food systems:

- business relations between the partners in the chain are primarily based on trust. One of the strategic partners is commonly recognized as key actor who makes large contributions to a well-organized chain

- farmers are treated the same as a strategic partner with all the rights and obligations to risktaking, governance and decision-making in the food chain,
- obligations and rights of the chain management equally apply to all actors in the chain,

- coordination (logistic and management) within the individual actors and among the groups of actors in the chain are coordinated at local, regional, national and / or international levels.

Furthermore, to ensure that Planika food chain expresses all stated characteristics of VBFC, three interviews were carried out. The first one taking place in the production sector (dairy farmers producing milk for Planika), the second one occurred with the processing sector (Planika dairy) and the last one was performed with several consumers from local shops (Prišenk, 2015).

\section{Data sources}

For purposes of econometric modelling (two different translog profit function models are described in subsection "model development"), data were obtained from the local Dairy called Planika, Agricultural Institute of Slovenia and Slovenian statistical portal. Survey input data are supported by questionnaires prepared for farmers (actors in Planika VBFC) to compile empirical data, mainly accounting data which provide the greatest credibility for empirical results gained (Pöldaru et al., 2005; Henningsen, 2014). Altogether, 26 face-toface questionnaires were carried out by well qualified examiners between July and December 2014. As the questionnaires could be classified as subjective methods (Barjolle et al., 2009), which is

Table 1. Description of model variables

\begin{tabular}{|c|c|c|}
\hline Sign & Name of variable & Description of variable \\
\hline$x_{1}$ and $x_{11}$ & $\begin{array}{l}\text { Average purchase price of milk paid } \\
\text { by Planika dairy }\left(x_{1}\right) \text { and Slovenian } \\
\text { low land dairies }\left(x_{11}\right)\end{array}$ & $\begin{array}{l}\text { Variables describe the average monthly purchase price of raw milk } \\
(€ / \mathrm{L}) \text { paid by Planika dairy and the average monthly purchase } \\
\text { price of milk }(€ / \mathrm{L}) \text { on Slovenian market (mainly low land market). } \\
\text { The purchase prices present "franco» farms prices known also as } \\
\text { "houses" prices excluding the transport costs. }\end{array}$ \\
\hline$x_{2}$ and $x_{22}$ & $\begin{array}{l}\text { Quantity of milk collected by } \\
\text { Planika dairy }\left(x_{2}\right) \text { and by other } \\
\text { Slovenian dairies }\left(x_{22}\right)\end{array}$ & $\begin{array}{l}\text { The variables denote the sum of monthly quantities of raw milk (L) } \\
\text { collected from the mountain farms (by Planika dairy) and sum of } \\
\text { monthly quantities of raw milk collected from other } \\
\text { Slovenian dairy farms (mostly located in low land areas). }\end{array}$ \\
\hline$x_{3}$ and $x_{33}$ & $\begin{array}{l}\text { Selling quantities of consumption } \\
\text { milk by Planika dairy }\left(x_{3}\right) \text { and sum } \\
\text { of selling quantities of consumption } \\
\text { milk low land dairies }\left(x_{33}\right)\end{array}$ & $\begin{array}{l}\text { The sum of monthly selling quantities of consumption } \\
\text { (drinking) milk by Planika dairy and sum of selling quantities } \\
\text { of consumption (drinking) milk on Slovenian market } \\
\text { (data from the rest } 3 \text { biggest dairies in low land areas in Slovenia). }\end{array}$ \\
\hline$x_{4}$ and $x_{44}$ & $\begin{array}{l}\text { Cost price of milk on mountain } \\
\text { farms }\left(x_{4}\right) \text { and cost price of milk } \\
\text { produced by Slovenian low land } \\
\text { farms }\left(x_{44}\right)\end{array}$ & $\begin{array}{c}\text { The average monthly cost prices of milk }(€ / \mathrm{L}) \text { from mountain farms } \\
\text { have been collected from their analytical calculations, while the } \\
\text { cost prices of milk }(€ / \mathrm{L}) \text { produce on Slovenian low land farms were } \\
\text { obtained from calculations from AIS. Both analytical calculations are } \\
\text { based on the intensity of milk production between } 4500 \mathrm{~L} \\
\text { and } 6500 \mathrm{~L} \text {, which stands for the competitive intensity of } \\
\text { milk production in Slovenian mountain areas. }\end{array}$ \\
\hline
\end{tabular}


considered as a kind of disadvantage for our research, the questions were mostly closed in order to make the answers more objective. Input data have been linked mainly to the purchasing prices of milk, the quantity of milk collection, selling quantities and selling prices of consumption (drinking) milk as the most important agricultural product on Slovenian and EU markets. One of the most important data for estimating the financial result (profit) with translog profit function model is the producer price of milk in mountain (hilly) and low land areas. Irrespective of the variables, we gathered a time series of 60 monthly data in the range of five years between 2009 and 2013, which in total implies a collection of 3600 input data, respectively. Model variables are described in Table 1. The sum and average values of data from Table 1 are subsequently presented in Table 2 .

\section{A model development process}

To translate the theoretical profit function into an econometric model, several assumptions must be made. Estimation of the profit 'share' equations is possible, given the sufficient degrees of freedom, which renders possible estimation of simultaneous-equations models. In one of the study author (Antle, 1984) clearly demonstrates that by applying Hotelling lemma to translog profit function, one obtains input demand and output supply functions. Henceforth, input demand and output supply elasticities based on the translog function can be derived.

Empirical literature has shown that efficiency could be measured from a production function or a profit function approaches. The profit function approach is much more helpful when individual or sole enterprises are considered (Nwachukwu and Onyenweaku, 2007). Translog form of profit function is a widely used functional design and affordable second-degree function (Steine et al., 2008). It can be approximated as a second-order of each function, like the Cobb-Douglas function, which gives an approximation of the first order. Translog profit function has proven to be very flexible and also offers a variable elasticity (Jenko, 2006).

The Normalized Restricted Translog Profit Function Approach was used here (Steine et al., 2008; Jenko, 2006; Pavalescu, 2011):

$$
L n \pi=a_{0}+\sum_{i} a_{i} \ln p_{i}+\sum_{m} b_{m} \ln z_{m}+\frac{1}{2 \sum_{i, j} b_{i j} \ln p_{i} \ln p_{j}}+\frac{1}{2 \sum_{m, n} c_{m n} \ln z_{m} \ln z_{n}}+\sum_{i, m} d_{i m} \ln p_{i} \ln z_{m}+u_{t}
$$

Where:

$\pi$ - restricted profit, normalized by the output price

$p_{i}$ - price of ith input $(\mathrm{Pi})$ normalized by the output price for all $\mathrm{i}=\mathrm{j}$

$z_{m}$ - quantity of fixed input

$a_{0}, a_{i}, b_{m}, b_{i j}, c_{m n}$ and $d_{i m}$ - parameters to be estimated.

$u_{t}$ - random error

Table 2. The sum and average values of monthly input data from 2009 to 2013

\begin{tabular}{cccc}
\hline & Sum & Mean & Unit \\
\hline $\mathrm{x}_{1}$ & 18.39 & 0.33 & $€ / \mathrm{L}$ \\
\hline $\mathrm{x}_{11}$ & 17.18 & 0.30 & $€ / \mathrm{L}$ \\
\hline $\mathrm{x}_{2}$ & 43037943 & 753304 & $\mathrm{~L}$ \\
\hline $\mathrm{x}_{22}$ & 1719046589 & 29553724 & $\mathrm{~L}$ \\
\hline $\mathrm{x}_{3}$ & 11236545 & 201391 & $\mathrm{~L}$ \\
\hline $\mathrm{x}_{33}$ & 24374732 & 479290 & $\mathrm{~L}$ \\
\hline $\mathrm{x}_{4}$ & 24.41 & 0.44 & $€ / \mathrm{L}$ \\
\hline $\mathrm{x}_{44}$ & 23.39 & 0.40 & $€ / \mathrm{L}$ \\
\hline $\mathrm{y}_{1}$ & 56.51 & 0.76 & $/$ \\
\hline $\mathrm{y}_{11}$ & 59.85 & 0.73 & $/$ \\
\hline
\end{tabular}


Based on the defined translog profit function [1], our translog profit function has the form presented by equation [2], which was used for analysis of the milk producer "profit share". Two translog profit functions have been developed given the endogenous variables (one predicting the trend in the share of profits of farms producing milk for Planika dairy, the second forecasting the "profit share" of farms producing milk for other Slovenian processors). Accordingly, their names were "PLANIKA translog profit function" and "SLO translog profit function", respectively. The structure of both is presented by the following equation:

$$
\begin{aligned}
\operatorname{Lny}_{(\text {SLO, PLANIKA })}= & A+a \ln x_{1}+b \ln x_{2}+c \ln x_{3}+d \ln x_{4}+a_{1}\left(\ln x_{1} * \ln x_{2}\right)+b_{1}\left(\ln x_{1} * \ln x_{3}\right)+c_{1}\left(\ln x_{1} * \ln x_{4}\right)+d_{1}\left(\ln x_{2} * \ln x_{3}\right) \\
& +e\left(\ln x_{2} * \ln x_{4}\right)+f\left(\ln x_{3} * \ln x_{4}\right)+a_{2}\left(\ln x_{1}\right)^{2}+b_{2}\left(\ln x_{2}\right)^{2}+c_{2}\left(\ln x_{3}\right)^{2}+d_{2}\left(\ln x_{4}\right)^{2}+u_{t}
\end{aligned}
$$

Where:

$y$ - restricted profit $\left(y_{S L O}\right.$ and $\left.y_{\text {PLANIKA }}\right)$

$x_{1}$ - average purchase price of milk in Planika dairy / or the average purchase price of milk in Slovenia $(€ / \mathrm{L})$

$x_{2}$ - the quantity of milk bought from dairy farms by Planika dairy / or quantity of milk bought by dairy farms in Slovenia (L/month)

$x_{3}$ - realization of drinking milk by Planika dairy on Slovenian market / or the total month realization of drinking milk in Slovenia (L/month)

$x_{4}$ - the producer price of milk on the mountain farms / or the producer price of milk on lowland farms in Slovenia $(€ / \mathrm{L})$

$a, b, c, d, a_{1}, b_{1}, c_{1}, d_{1}, e, f, a_{2}, b_{2}, c_{2}, d_{2}$ - estimated parameters, $u_{t}$ - random error.

Restricted profit is obtained by subtracting the cost of variable inputs (the producer price of milk) from total revenue (the purchase price of milk). After the model estimation, the calculation of profit elasticities was made (Junaid et al., 2014).

These are defined as:

$\partial \ln \pi / \partial \ln p_{i}$

for the elasticity of profit with respect to changes in input prices and

$\partial \ln \pi / \partial \ln z_{m}$

for the profit elasticity with respect to changes in fixed inputs.

In both cases, the translog profit functions (Planika and SLO) dependent variables (y) were less than 1 , which means that the producer price of milk was greater than the purchasing milk prices. These values explain that farmers have slightly higher costs incurred to the milk production as it is reflected in the purchasing price of milk. Therefore, one cannot convincingly argue about the "profit share", but rather about the "share of loss" that milk farmers face. Elasticity translog profit function is therefore taken as the inverse ratio of accidentals; in the plus $(+)$ is now transformed into the minus (-) and vice versa. Negative indicators of profit functions have also been described by some authors (Bos and Koetter, 2011).

\section{Results and discussion}

The results of statistical and econometric tests for the PLANIKA translog profit function are presented in Table 3, and for the SLO translog profit function are given in Table 4.

Calculated elasticities of the independent variables from the equations presented in section 3.2.4 can be gleaned from Table 5. Results of translog profit function have shown that in the case of an increase of purchase prices of milk by $1 \%$, the Planika Dairy 'share of loss' will decrease by $0.44 \%$, while in the case of the Slovenian average the corresponding loss amounts to $1.32 \%$. The share of loss would also be reduced to $0.61 \%$ in the case of an increase in the quantities of milk purchased in Slovenia, while increasing the quantities of milk purchased by the Planika Dairy would not have any positive or negative impacts whatsoever on the change in the loss of farms $(0.00 \%)$. In the case of independent variables $\mathrm{X}_{1}$ and $\mathrm{X}_{2}$, the PLANIKA translog profit function showed worse results for dairy farms compared with SLO translog profit function, while in the case of independent variables $\mathrm{X}_{3}$ and $\mathrm{X}_{4}$ the farms producing milk for Planika dairy can expect better financial position. Thus, the share of loss in the case of 1-percent increase of realization of drinking milk from Planika 
Table 3. Features of PLANIKA translog profit function

\begin{tabular}{|c|c|c|c|}
\hline & $\begin{array}{r}\text { Depen } \\
\text { Meth } \\
\text { Date: } 06 \\
\text { Sample (adjus } \\
\text { cluded obser }\end{array}$ & $\begin{array}{l}\text { LNY } \\
\text { ares } \\
20: 33 \\
012013 \mathrm{Ml} 2 \\
\text { er adjustments }\end{array}$ & \\
\hline Variable & Coefficient & Std. Error & t-Statistic \\
\hline Constant & 12.54689 & 16.65410 & 0.753382 \\
\hline Lnxl & 7.870622 & 4.704085 & 1.673146 \\
\hline Lnx2 & 1.112828 & 1.229041 & 0.905444 \\
\hline Lnx3 & -2.584886 & 2.407920 & -1.073493 \\
\hline $\operatorname{Lnx} 1 * \operatorname{Lnx} 2$ & 0.154675 & 0.217233 & 0.712022 \\
\hline LNX1 ${ }^{*} \operatorname{Lnx} 3$ & -0.784846 & 0.428137 & -1.833166 \\
\hline LNX2*LNX3 & -0.215536 & 0.129376 & -1.665968 \\
\hline $\mathrm{LNX1}^{* * 2}$ & 0.158522 & 0.598781 & 0.264741 \\
\hline LNX2**2 & 0.062844 & 0.037765 & 1.664072 \\
\hline LNX3**2 & 0.189740 & 0.119459 & 1.588324 \\
\hline \multicolumn{4}{|c|}{ Values od statistical and econometric tests } \\
\hline R-squared & 0.733478 & Mean dependent var & 0.006780 \\
\hline Adjusted R-squared & 0.677952 & S.D. dependent var & 0.011103 \\
\hline S.E. of regression & 0.006301 & Akaike info criterion & -7.129648 \\
\hline Sum squared resid & 0.001906 & Schwarz criterion & -6.742311 \\
\hline Log likelihood & 221.3246 & Hannan-Quinn criter. & -6.978447 \\
\hline F-statistic & 13.20976 & Durbin-Watson stat & 2.244904 \\
\hline Prob(F-statistic) & 0.000000 & & \\
\hline
\end{tabular}

Table 4. Features of SLO translog profit function

\section{Dependent Variable: LNY}

Method: Least Squares

Date: 05/19/16 Time: 20:45

Sample (adjusted): 2009M01 2013M12

Included observations: 60 after adjustments

\begin{tabular}{cccc}
\hline Variable & Coefficient & Std. Error & t-Statistic \\
\hline Constant & -25.59358 & 23.14845 & -1.105629 \\
\hline Lnxl & 2.117690 & 2.217081 & 0.955170 \\
\hline Lnx2 & 3.373147 & 4.146804 & 0.813433 \\
\hline Lnx3 & 1.465133 & 1.137733 & 1.287766 \\
\hline Lnx1 ${ }^{*}$ Lnx2 & -0.244312 & 0.204510 & -1.194618 \\
\hline LNX1 ${ }^{*}$ Lnx3 & 0.074750 & 0.086251 & 0.866654 \\
\hline LNX2 ${ }^{\text {LNX3 }}$ & -0.065037 & 0.109694 & -0.592898 \\
\hline LNX1**2 & 1.003402 & 0.823297 & 1.218761 \\
\hline LNX2**2 & -0.684862 & 1.026404 & -0.667244 \\
\hline LNX3**2 & -0.134359 & 0.131516 & -1.021617 \\
\hline & Values od statistical and econometric tests & \\
\hline R-squared & 0.854043 & Mean dependent var & 0.030400 \\
\hline Adjusted R-squared & 0.822314 & S.D. dependent var & 0.015091 \\
\hline S.E. of regression & 0.006361 & Akaike info criterion & -7.105648 \\
\hline Sum squared resid & 0.001861 & Schwarz criterion & -6.711375 \\
\hline Log likelihood & 213.5110 & Hannan-Quinn criter. & -6.952420 \\
\hline F-statistic & 26.91622 & Durbin-Watson stat & 2.099228 \\
\hline Prob(F-statistic) & 0.000000 & &
\end{tabular}


dairy will decrease by $0.14 \%$, while in the case of SLO translog profit function the corresponding loss will be only $0.04 \%$. Even more encouraging is the fact that in the case of increasing the cost of milk production by $1 \%$, less losses suffered the farmers producing milk for Planika dairy $(0.52 \%)$, while the farmers producing milk in other Slovenian dairies experienced a higher loss (1.10\%). Very stimulating finding for the farmers from hilly-mountain regions is also that cost increases would obviously have less negative economic impacts on their performance as is the case with their counterparts in lowland areas.

Empirical results showed a positive financial impact on dairy farms if they are part of the value-based food chain (Planika dairy). The difference between the producer price and the purchase price of milk will be reduced assuming an increase in the buying price of drinking milk by $1 \%$. The estimated production costs of milk are higher between 10-20\% for farms in upland areas compared to farmers operating in lowland areas. This outcome does not meet our previous assumption since we anticipated lower costs of milk production due to the inclusion of a large proportion of grass in the animal feed ration. This is primarily the result of the nature of the labour - majority share of the labour represents the manual and not mechanical work, which in turn leads to a financially less favourable situation for farmers. If we focus on the success of sales of drinking milk as a main milk product on the market solely, the calculated average price elasticity models SLO and PLANIKA suggest better economic performance of farms which are part of value-based food chains. Even more encouraging fact for upland farmers is that an increase of the production costs of milk had less negative economic returns for upland farms than was the case with the lowland producing dairy farms.
These findings are especially important in such studies where economic behaviour of milk producers originating from different geographical areas is under the scrutiny. One of the principal goals of this research was to determine the discrepancies arising from these different dairying enterprises. Evidence suggest that dairy farmers operating in low-land areas were obviously not provided strong economic incentives to adopt new production challenges as was clearly the case with their counterparts, dairy farmers in mountain regions.

Some studies (Jan et al., 2014; Prišenk 2015) have clearly demonstrated the environmental and economic competitive disadvantage of milk production under unfavourable natural production conditions. This finding may, to some extent, question the appropriateness of milk production under such conditions. However, it should be additionally taken into account that dairy farms located in (unfavourable) mountain areas are characterized by their multifunctionality, that is, by their multiple functions going far beyond the sole food production function. Hence, the Planika dairy has both organic and non-organic production lines and ensures farmers to switch from conventional to organic production type. From a farmer's perspective in Swiss mountain regions, the results of the one study (Flubacher et al., 2015) suggest that switching from conventional to organic production can improve the farm's income. This does not guarantee that switching from conventional to organic farming leads to an immediate improvement of the economic situation as discussed by some authors (Pažek and Rozman, 2008). It rather indicates that switching to organic farming might improve the economic performance in the long run but not in the short run.

Table 5. The values of elasticities computed from PLANIKA and SLO translog profit functions

ELASTICITY VALUES OF TRANSLOG PROFIT FUNCTIONS

\begin{tabular}{ccc}
\hline INDEPENDENT VARIABLE & $\begin{array}{c}\text { PLANIKA TRANSLOG PROFIT } \\
\text { FUNCTION }\end{array}$ & $\begin{array}{c}\text { SLO TRANSLOG PROFIT } \\
\text { FUNCTION }\end{array}$ \\
\hline $\mathrm{X}_{1}$ & -0.44 & -1.32 \\
\hline $\mathrm{X}_{2}$ & 0.00 & -0.61 \\
\hline $\mathrm{X}_{3}$ & -0.14 & -0.04 \\
\hline $\mathrm{X}_{4}$ & 0.52 & 1.10 \\
\hline
\end{tabular}


Our study may give an insight into this new subject on a farm level, and could at the same time deliver a valid empirical framework (dimension) in further debate about CAP post-2020 developments. After all, the guidelines and remittances for CAP after 2020 appear yet (Falkenberg, 2006; European Parliament, 2016; The Netherlands EU Presidency, 2016). Common to all discussions about future creating of CAP is one topic: How can farmers be better equipped to improve their position in the supply chain? One of the discussion paper (The Netherlands EU Presidency, 2016) explain the farmers' share in the value chain is decreasing and incomes are generally very modest compared to the profits higher up in this chain. Structural changes in the food chain have raised policy questions on the functioning of the food chain and the need to increase the bargaining power of the agricultural sector. Increasing the share for the farmers in the food chain may reduce the need for income support and therefore raises questions on the role of the CAP in income support. The Commission factsheet also notes that "many EU consumers prefer local or regional products where these are available. As a result, farmers are increasingly selling directly to consumers at farmers' markets and are processing their own products to add local value" (Falkenberg, 2016). This trend should not be underestimated and could be a key element to re-establish the Common Agricultural Policy into its first function: to increase farm revenue and to provide quality food to European citizens. Eurobarometer highlights that the majority of Europeans consider two priorities as being "very important": investing in rural areas to stimulate economic growth and job creation (47\%), and strengthening the farmer's role in the food chain (45\%) (Falkenberg, 2016). To that end, the future CAP must be structured around three principal European objectives (CAP 2020, 2017): i) Strengthening the sector's resilience in order to cope with a wide range of hazards, ii) Contributing to growth and jobs, underpinned by innovation and a transition to new models of production and iii) Responding to environmental and climatic challenges and helping ensure a proper balance in rural areas. The above objectives could be pursued with measures on three axes (CAP 2020, 2017): i) An axis for growth, jobs and competitiveness in European supply chains (agricultural, food and non-food), ii) An axis for environmental public goods and the development of the territories, especially those with natural handicaps and iii) An axis for resilience in coping with sanitary, climatic and economic hazards.

Last but not least, our study findings can improve the discussion in the way to support farmers included in food chains with the aim to strength their financial position. After all, when dairy cooperatives are considered similar to Producer Organizations regarding contracts, since they dispatch value added to their members, more than half of Member States hold at least $50 \%$ of deliveries covered by organized contractual relations with collectors (European Parliament, 2016).

\section{Conclusion}

The model developed in this study has been structured to examine the effects of value-based agro food chains on the performance of mountainous dairy farms. Translog profit model alleviates the path of understanding in explaining the better economic situation of these high-land dairy farms stemming from their capability to adjust adequately and promptly to ongoing changes in the milk market. The obvious outcome is that any price change provokes different outcomes on the performance of up-land and down-land milk farms alike. This specific implication could be relevant to analyse further alignment of dairy farms pertinent to their origin.

Recent years have seen a certain number of empirical analyses based on duality and derived from profit functions. Such models have the advantage that they can easily generate multiple outputs and inputs, providing that accurate input and output prices are available. If there potentially is limited data availability, the econometric models and their estimates are not entirely reliable. A richer class of models would, hence, be needed to provide a more complete understanding of the data. The one that appears more challenging within the class presented here is the incorporation of simultaneous-equation modelling approach which could distinguish between the two types of dairy farms, should the accurate price information allow this methodological upgrading. 


\section{Prehrambeni lanci temeljeni na vrijed- nosti kao prilika ekonomskog prosperiteta mliječnih gospodarstava: metoda translog funkcije profita}

\section{Sažetak}

U radu se koriste raspoloživi statistički podaci i translog funkcija profita procjene performansi mliječnih farmi koje se nalaze u planinskim i nizinskim područjima Slovenije. Translog model profita pokazuje trend koji objašnjava bolji ekonomski učinak mliječnih gospodarstava $u$ planinskim područjima kao posljedicu njihove sposobnosti prilagodbe glavnim promjenama na tržištu mlijeka. Empirijska analiza pokazuje trend neelastičnosti cijena mlijeka. Translog model profita prikazuje ekonomsku situaciju promatranih gospodarstava kao posljedicu njihove sposobnosti adekvatnom i brzom prilagođavanju stalnim promjenama na tržištu. Zaključno, rezultati ove analize mogu doprinijeti novoj dimenziji rasprave o razvoju ZPP-a nakon 2020. godine.

Ključne riječi: lanac poljoprivredno-prehrambenih proizvoda, dodana vrijednost, mliječne farme, planinska područja, translog funkcija profita

\section{References}

1. Agricultural Institute of Slovenia (AIS) (2013): The report on the state of agriculture, food, forestry and fisheries in 2013. http://www.kis.si/f/docs/Porocila_o_stanju_v kmetijstvu_OEK/ZP-2013-splosnopriloge.pdf (accessed 20 December 2016).

2. Antle, J.M. (1984): The Structure of U.S. Agricultural Technology 1910-78. American Journal of Agricultural Economics 66 (4), 414-421. https://doi.org/10.2307/1240919

3. Barjolle, D., Paus, M., Perret, A. (2009): Impacts of geographical indications review of methods and empirical evidences. Paper Presented at the IAAE Conference. Beijing, China. 2009.

4. Bernet, T., Staal, S., Walker, T. (2001): Changing milk production trends in Peru. Small-scale highland farming versus coastal agribusiness. Mountain Research and Development 21 (3), 268-275. https://doi.org/10.1659/0276-4741(2001)021 [0268:CMPTIP]2.0.CO;2
5. Beyers, L., Hassan, R. (2000): The structure of South African milk production technology: A parametric approach to supply analysis. Working paper 2000-04. University of Pretoria, Department of Agricultural Economics, South Africa. 2000.

6. Bos, JWB., Koetter, M. (2011): Handling Losses in Translog Profit Models. Applied Economics 43 (3), 307-312. https://doi.org/10.1080/00036840802570413

7. CAP 2020 (2017): Informal Council on the post-2020 CAP. French contribution to the 29/31 May 2016 Informal Council on the post-2020 CAP. file:///C:/Users/ Pri\%C5\%Alenk/Downloads/160525_fr_contribution to_the_post-2020_cap.pdf (accessed 17 January 2017).

8. EuroActiv (2016): European farmers fear instability as milk market deregulated. https://www.euractiv.com/ section/agriculture-food/news/european-farmers-fearinstability-as-milk-market-deregulated/ (accessed 25 March 2016)

9. European Commission (2016): EU prices of cow's raw milk. Milk Market Observatory. http://www.clal.it/ upload/eu-raw-milk-prices_en\%202016-09-08.pdf (accessed 5 November 2016).

10. European Commission (2015): EU prices of cow's raw milk. Milk Market Observatory. (2015). http:// www.informatorezootecnico.it/wp-content/uploads/ sites/15/2015/09/AGOSTO-2015-eu-raw-milk-pricesen.pdf (accessed 6 February 2016).

11. European Commission (2014): Commission study explores use of "mountain product" label. (2014). https:// ec.europa.eu/agriculture/newsroom/104_en (accessed 25 April 2016).

12. European Parliament (2016): Research for AGRI Committee - CAP REFORM POST-2020 - Challenges in Agriculture. Workshop documentation. Brussels, European Union, October http://www.europarl.europa.eu/committees/en/supporting-analyses-search.html (accessed on 2. February 2017).

13. European Parliament (2013): Report of the conservation of milk production in mountainous areas, LFA areas and dislocated regions after the of the milk quota system falling. http://ec.europa.eu/eurostat/statistics-explained/ index.php/Milk_and_milk_products_-_30_years_of_ quotas (accessed 10 January 2017).

14. Falkenberg, K. (2016): Sustainability Now! A European Vision for Sustainability. EPSC Strategic Notes. http:// ec.europa.eu/epsc/sites/epsc/files/strategic_note_issue_18.pdf (accessed on 20 November 2016).

15. Flubacher, M., Sheldon, G., Müller, A. (2015): Comparison of the economic performance between organic and conventional dairy farms in the Swiss mountain region using matching and stochastic frontier analysis. Journal of Socio-Economics in Agriculture 7 (1), 76-84.

16. Henningsen, A. (2014): Introduction to Econometric Production Analysis with $R$ (Draft Version). Department of Food and Resource Economics, University of Copenhagen. http://files.itslearning.com/data/ku/103018/teaching/lecturenotes.pdf (accessed 9 October 2014). 
17. Jan, P., Dux, D., Lips, M., Alig, M., Baumgartner, DU. (2014): Analysis of the determinants of the economic and environmental performance of Swiss dairy farms in the alpine area. Proceedings of the $9^{\text {th }}$ International Conference on Life Cycle Assessment in the Agri-Food Sector (LCA Food 2014), San Francisco, California, USA, 8-10 October, 2014.

18. Jenko, J. (2006): The responsiveness of pork supply. B.Sc. Diploma work. University of Ljubljana, Biotechnical faculty.

19. Junaid, S., Ali, S., Ali, S., Jan AU., Shah, A. (2014): Supply response analysis of rice in Pakistan: normalized restricted translog profit function approach. International Journal of Innovation and Applied Studies 7 (3), 826831.

20. Kneafsey, M., Venn, L., Schmutz, U., Balázs, B., Trenchard, L., Eyden-Wood, T., Bos, E., Sutton, G., Blackett, M. (2013): JRC Scientific and Policy Reports - Short Food Supply Chains and Local Food Systems in the EU. A State of Play of their Socio-Economic Characteristics. Publications Office of the European Union, Luxembourg.

21. Nwachukwu, IN., Onyenweaku, CE. (2007): Economic efficiency of Fadana Telfairia production in Imo State Nigeria: A translog profit function approach. Journal of agricultural research and policies 4 (2), 87-93.

22. Malla, Y. (2007): Dairy farming in mountain areas. Mountain Research and Development 27 (3), 291-292. https://doi.org/10.1659/mrd.mm018

23. Mawa, L.I., Kavoi, M.M., Baltenweck, I., Poole, J. (2014): Profit efficiency of dairy farmers in Kenya: An application to smallholder farmers in Rift Valley and Central Province. Journal of development and agricultural economics 6 (11), 455-465.

24. Ministry of Agriculture, Forestry and Food (MKO) 2016: http://www.mkgp.gov.si/en/ (accessed 6 September 2016).

25. Musshof, O., Hirschauer, N., Herink, M. (2009): When should (shouldn't) one use Data Envelopment Analysis. A critical appraisal. German Journal of Agricultural Economics 58 (2), 114-124.

26. Pavelescu, FM. (2011): Some aspects of the translog production function estimation. Romanian Journal of Economics 41 (1), 131-150.

27. Pažek, K., Rozman, Č. (2008): The real options approach for assessment of business opportunities in spelt processing. Agricultura 6 (1), 13-17.

28. Pearson, D., Henryks, J., Trott, A., Jones, P., Parker, G., Dumaresq, D., Dyball, R. (2011): Local Food: Understanding Consumer Motivations in Innovative Retail Formats. British Food Journal 133 (7), 886-899. https://doi.org/10.1108/00070701111148414
29. Pirog, R., Bregendahl, C. (2012): Creating Change in the Food System: The role of regional food networks in lowa. http://www.ams.usda.gov/AMSvl.0/getfile?dDocName =STELPRDC5105337 (accessed 15 September 2016).

30. Pöldaru, R., Roots, J., Viira, AN. (2005): Estimating econometric model of average total milk cost: A support vector machine regression approach. Economics and rural development 1 (1), 23-31.

31. Prišenk, J. (2015): The effects of value based agro-food chain on the socio-economic situation of dairy farms in mountain regions. $\mathrm{Ph}$. D. Thesis. University of Maribor, Faculty of Agriculture and Life Sciences.

32. Steine, G., Kristofersson, D., Guttormsen, A.G. (2008): Economic evaluation of the breeding goal for Norwegian Red Dairy Cattle. Journal of Dairy Science 91 (1), 418-426. https://doi.org/10.3168/jds.2006-747

33. Stevenson, G.W. (2013): Value-based food supply chains. Shepherd`s Grain. http://cias2.andywhitewebworks.com/wp-ontent/uploads/2013/06/shepherdsgrainfinal0716131.pdf (accessed 5 May 2014).

34. Stevenson, G.W., Clancy, K., King, R., Lev, L., Ostrom, M., Smith, S. (2011): Midscale food value chains: An introduction. Journal of Agriculture, Food Systems and Community Development 1 (4), 27-34. https://doi.org/10.5304/jafscd.2011.014.007

35. Stevenson, G.W., Pirog, R. (2008): Values-Based Supply Chains: Strategies for Agrifood Enterprises-of-theMiddle. In Renewing an Agriculture-of-the Middle: Situation and Strategy for the Center of the U.S. Food System (Penn State Press), T. Lyson, G. Stevenson, and R.Welsch, eds.

36. The Netherlands EU Presidency. Food of the future. (2016): Discussion paper of the Netherlands Presidency. https://english.eu2016.nl/documents/publications/2016/05/31/food-of-the-future (accessed 20 December 2016).

37. Vacas, LR., Muenchhausen, SV., Haering, AM. (2014): Strategies for medium-sized value-based food chains during growing process with a particular focus on the business logic and management. Organicprintsl.org. http:// orgprints.org/24924/7/24924.pdf (accessed 11 November 2015).

38. Viitaharju, L., Lähdesmäki, M., Kurki, S., Valkosalo, P. (2005): Food Supply Chains in Lagging Rural Regions of Finland: an SME Perspective. University of Helsinki. Available online: https://helda.helsinki.fi/bitstream/ handle/10138/17733/Publications4.pdf? sequence $=1$ (accessed November 10, 2015).

39. Witzke, P., Kempen, M., Dominguez Perez, I., Jansson, T., Sckokai, P., Helming, J., Heckelei, T., Moro, D., Tonini, A., Fellmann, T. (2009): Regional Economic Analysis of Milk Quota Reform in the EU. JRC Scientific and Technical Reports. European Commission. 